\title{
Working
}

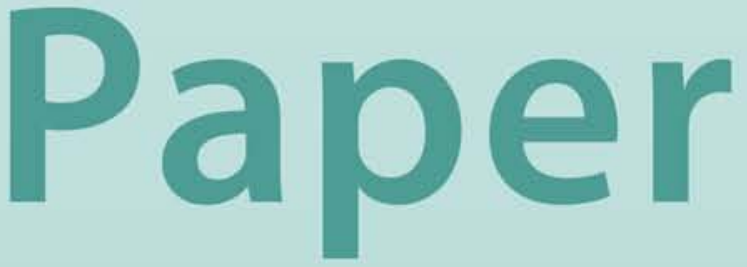




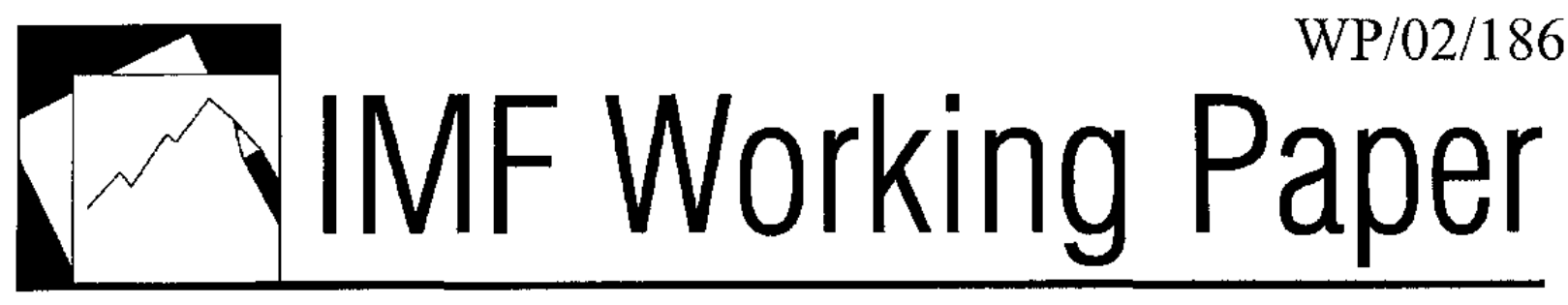

\section{Consolidation and Market Structure in Emerging Market Banking Systems}

R. Gaston Gelos and Jorge Roldós 


\title{
IMF Working Paper \\ International Capital Markets Department
}

\section{Consolidation and Market Structure in Emerging Market Banking Systems}

\author{
Prepared by R. Gaston Gelos and Jorge Roldós ${ }^{1}$ \\ Authorized for distribution by Donald J. Mathieson
}

November 2002

\begin{tabular}{l} 
Abstract \\
$\begin{array}{l}\text { The views expressed in this Working Paper are those of the author(s) and do not necessarily } \\
\text { represent those of the IMF or IMF policy. Working Papers describe research in progress by the } \\
\text { author(s) and are published to elicit comments and to further debate. }\end{array}$ \\
\hline
\end{tabular}

This paper examines the evolution of market structure in emerging market banking systems during the 1990s. While significant bank consolidation has been taking place in these countries, reflected in a sharp decline in the number of banks, this process has not systematically been associated with increased concentration as measured by standard indices. Moreover, econometric estimates based on the Panzar-Rosse (1987) methodology suggest that, overall, markets have not become less competitive in a sample of eight European and Latin American countries. Lowering barriers to entry, by doing such things as allowing increased participation of foreign banks, appears to have prevented a decline in competitive pressures associated with consolidation.

JEL Classification Numbers: G21, L13, L51

Keywords: Banking, market structure, competition, emerging markets, Panzar and Rosse methodology, contestability

Authors' E-Mail Addresses: ggelos@imf.org; jroldos@imf.org

${ }^{1}$ The first version of this paper was written as a background paper for the IMF's International Capital Markets Report 2001. One of the authors, R. Gaston Gelos, is now in the Research Department but was a member of the International Capital Markets Department when the first version of this paper was prepared. The authors wish to thank Silvia Iorgova for research assistance; Susan Collins, Giovanni Dell'Ariccia, Linda Goldberg, and participants at the May 2002 conference, "Financial Globalization, A Blessing or a Curse?" for comments; and Luc Laeven for providing data. 


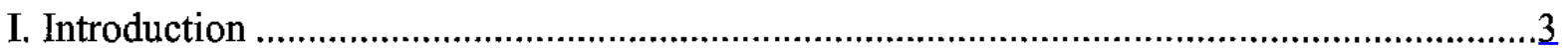

II. Patterns of Banking System Consolidation in Emerging Markets ...................................4

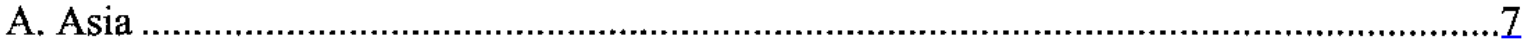

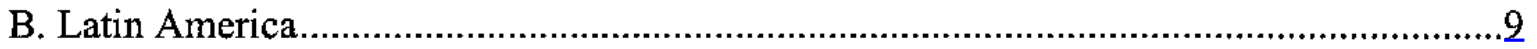

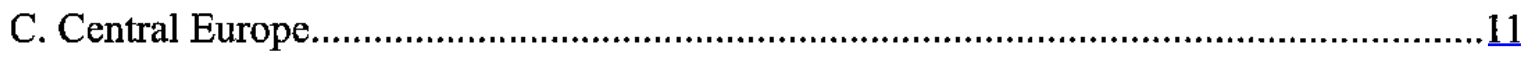

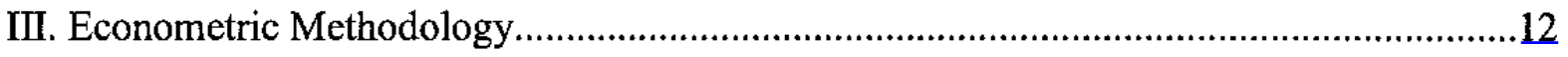

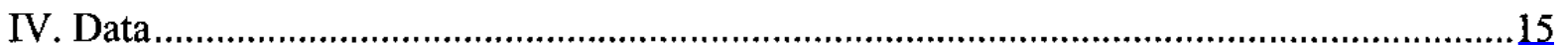

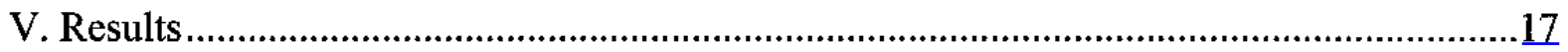

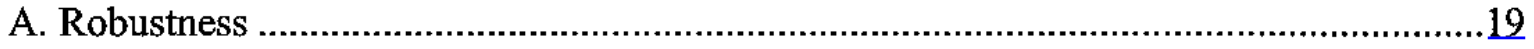

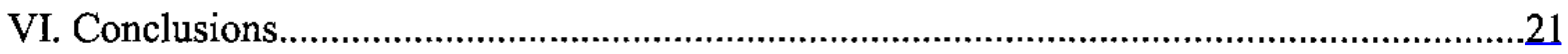

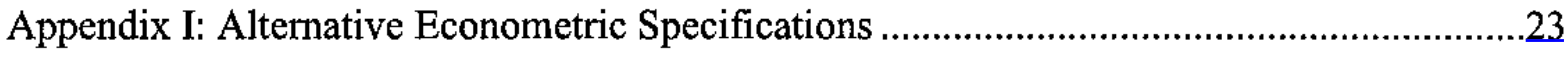

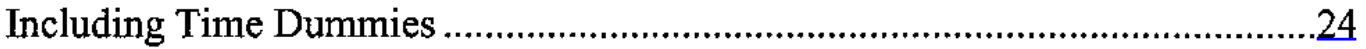

Using Personnel Expenses Divided by Number of Employees as

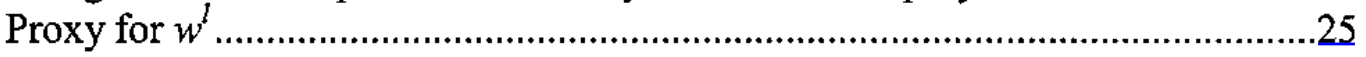

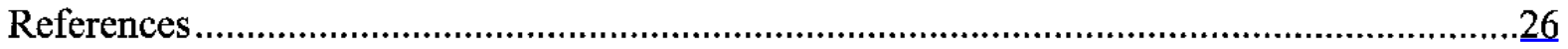

Tables

1. Number of Banks and Market Concentration in Selected Emerging Market Banking

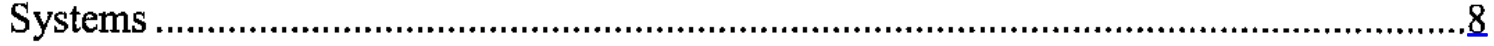

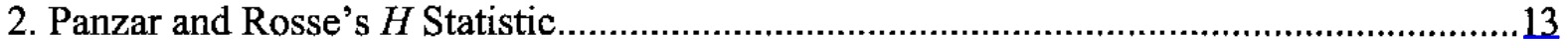

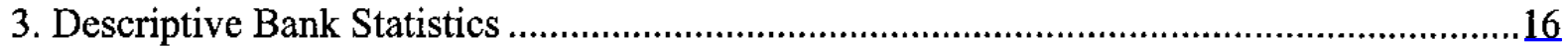

4. Fixed-Effects Estimation of Revenue Equation (2) ............................................ 18

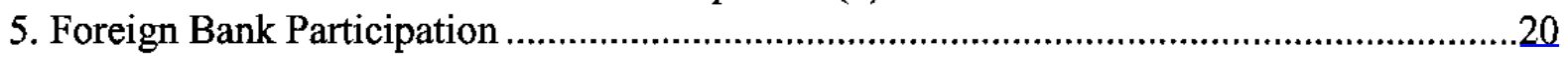

Figures

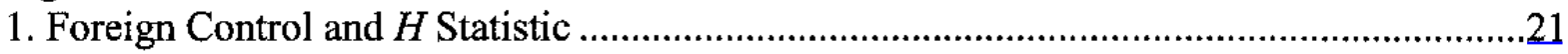




\section{INTRODUCTION}

The financial services industry has been subject to dramatic changes over the past decades as a result of advances in information technology, deregulation, and globalization. This has reduced margins in traditional banking activities, leading banks to merge with other banks as well as with nonbank financial institutions, both at home and abroad. The ongoing process of consolidation has raised a number of positive and normative issues for both mature and emerging banking systems (see, for instance, G-10, 2001, and IMF, 2001). In this paper, we review the main characteristics of the consolidation process in the major emerging market banking systems and study its impact on the market structure of the industry.

The forces driving the consolidation process are similar in both mature and emerging markets, but the latter show some distinguishing features. First, while cross-border mergers and acquisitions are the exception in mature markets, they account for a large share of the consolidation activity in emerging markets. Second, while consolidation in mature markets has served to eliminate excess capacity more efficiently than bankruptcy or other means of exit, in emerging markets consolidation has often been a way of dealing with problems stemming from financial crises. Third, the authorities have played a major role in the consolidation process in emerging markets, whereas market forces have been more dominant in the mature markets.

While a number of studies have examined the effects of bank consolidation on market structure in mature markets, hardly any systematic research has been carried out for emerging market economies. We attempt to fill this gap. First, we discuss the main forces shaping bank consolidation in major emerging markets and describe the patterns of consolidation and concentration using traditional indicators of market structure. Then, we employ the method developed by Panzar and Rosse (1987) to assess changes in the competitive structure in these markets following the consolidation process of the second half of the 1990s. This approach, which is based on the relationship between revenue and marginal costs, has typically been applied to cross-sectional data from developed countries. ${ }^{2}$ By contrast, the panel data approach followed here allows for assessing changes in market structure over time, in addition to providing more reliable estimates.

We find that while the number of banks has fallen in all the emerging markets covered in this study during the period 1994-2000, this decline has not systematically resulted in an increase in concentration. In Central Europe, for instance, a reduction of the number of banks has been associated with lower concentration - as measured by the share in total deposits of the largest banks and by Hirshman-Herfindahl $(\mathrm{HH})$ indices-since the large, formerly state-owned savings banks have been losing market share to the more dynamic medium-sized banks. In most of the Asian crisis countries, government-led restructuring processes have led to a reduction in the number of banks, but the degree of concentration has remained relatively stable. The process of bank consolidation is more

\footnotetext{
${ }^{2}$ Two exceptions are Bikker and Groeneveld (2000) and De Bandt and Davis (2000), who examine the competitive conditions in European markets.
} 
advanced in Latin America as a result of the earlier occurrence of crises and foreign bank entry; in this region, the reduction in the number of banks has been accompanied by a clear increase in the level of concentration in the industry.

There is no indication of a broad decline in the intensity of competition. In accordance with the results found in the literature for most of the mature markets, our estimates indicate that emerging banking markets are characterized by monopolistic competition. Moreover, our results suggest that lowering barriers to entry and allowing for increased participation of foreigners in domestic banking markets has, to some extent, offset any adverse effects on the intensity of competition brought about by consolidation in the banking sector. ${ }^{3}$ For example, there is a positive correlation between the index of competition intensity obtained through the Panzar-Rosse methodology and indices of foreign bank participation. However, the process is still evolving, and, particularly in Central Europe, it may still be too early to make a definitive assessment.

\section{Patterns of Banking System Consolidation in Emerging Markets}

The main forces encouraging consolidation in mature market banking systemsnamely globalization, advances in information technology, and deregulation-as well as those discouraging it-lack of information and transparency, cross-country differences in regulatory frameworks, ownership structures, and cultures - are also at work in emerging

markets. ${ }^{4}$ However, the relative importance of these factors varies across countries yielding patterns of consolidation that differ from those in the mature markets. The main features of the consolidation process in emerging markets, including the role of government-led restructuring and foreign bank entry, are discussed in this section. The discussion here is focused on traditional indicators of market structure, such as the share of the largest banks in total deposits and Herfindahl-Hirshman (HH) indices.

\footnotetext{
${ }^{3}$ The extent to which intense competition in the banking sector is desirable, is, of course, subject of considerable debate. See, for example, Bonaccorsi di Patti and Dell' Ariccia, forthcoming, for a summary of the literature on the effects of competition on lending behavior and Matutes and Vives (1996), or Cordella and Levy Yeyati (2002) for examples of studies of the link between bank competition and financial fragility. We do not address this normative question in this paper.

${ }^{4}$ See Group of Ten (2001) for a survey of the main causes of consolidation in industrialized countries.
} 
The most notable difference between the consolidation process in mature versus emerging markets is the overwhelming cross-border nature of mergers and acquisitions (M\&As) in the latter. ${ }^{5}$ In particular, as noted in the G-10 (2001) study, cross-border merger activity in continental Europe and also between U.S. and European institutions has been more the exception rather than the rule. In contrast, the staggering increase in foreign ownership of emerging market banks has continued unabated, with foreign institutions controlling more than half the banking system assets in Argentina, Chile, the Czech Republic, Hungary, Poland, and Mexico. In several Latin American and Central European countries, foreign banks are in the process of integrating previous acquisitions with some of the larger banks bought in the late $1990 \mathrm{~s}$, but it is expected that some foreign banks that do not reach market shares above 2-3 percent in a given country will exit the market in the near future. In addition, the merger of parent banks in the mature markets is spilling over to the local banking environments in both regions, accelerating the consolidation process and contributing to the creation of large, dominant institutions.

Another difference is the more important role played by the authorities-and the smaller role played by market forces-in the financial sector consolidation process of emerging markets. In mature markets, consolidation has been seen as a way of eliminating excess capacity more efficiently than bankruptcy or other means of exit, as it allows preservation of some of the preexisting franchise value of the merging firms. ${ }^{6}$ In emerging markets, consolidation has been predominantly a way of resolving problems of financial distress, with the authorities playing a major role in that process. As a result of implicit or explicit deposit guarantees, the banking authorities have usually intervened in troubled institutions and then sold them back to the private sector-as whole institutions or in purchase and assumption transactions. Even when consolidation was seen as a desirable outcome-during normal times or as a second stage of the crisis-resolution process - market forces appear to have often failed to deliver the desired outcome.

Ownership structures (in particular, family ownership) regulatory shortcomings, and concerns about job losses remain the main obstacles to a faster, market-driven consolidation process, except in the transition economies. In most emerging markets, local banks

\footnotetext{
${ }^{5}$ The extent and consequences of foreign ownership in emerging market banking systems has been studied extensively; see, for instance, Clarke, Cull, Martinez Peria, and Sánchez (2001); Mathieson and Roldós (2001), and the references therein to regional and individual country studies.

${ }^{6}$ See Berger, Demsetz, and Strahan (1999).
} 
started as family-owned institutions that in many cases became parts of industrial conglomerates. ${ }^{7}$ This ownership structure has at times combined with economic and prudential regulations to provide franchise value to institutions that would otherwise be taken over or liquidated. It is generally accepted that family businesses tend to be bigger and last longer in economies with less developed primary and secondary capital markets. Also, barriers to entry and regulations such as administered interest rates generate profits that would be absent in the absence of such regulations, and deficiencies in prudential regulation sometimes tend to perpetuate such inefficiencies. ${ }^{8}$ Only a few banks are publicly listed in emerging market banking systems, and this makes takeovers- both friendly and hostiledifficult to carry out. The need to restructure banking systems affected by crises in the second half of the 1990s created difficult tradeoffs for the parties involved. In some cases, the government asked acquiring institutions to minimize any negative employment implications, and in some cases agreements on employment freezes were reached. This may have hindered market-driven M\&As in some cases, but it does not appear to have been a major constraint in countries where a low level of bank penetration ensures rapid credit growth in the near term.

Although the importance of the different factors driving the consolidation process vary by country, there are some discernible patterns of consolidation across regions. These patterns can be summarized by a number of indicators, some of which are presented in Table 1 for a sample of selected emerging markets in 1994 and 2000 . The indicators are the number of banks in each country, the share of deposits of the largest banks, and the Herfindahl-Hirschman ( $\mathrm{HH})$ index. The $\mathrm{HH}$ index is a standard measure of consolidation in any industry and it is defined as the sum of the squared deposit market shares of all the banks in the market. By construction, the $\mathrm{HH}$ index has an upper value of 10,000 in the case of a monopolist firm with a 100 percent share of the market; the index tends to zero in the case of a large number of firms with very small market shares. A market with ten firms with equal shares would have an $\mathrm{HH}$ index of 1,000, but an uneven distribution of market shares may affect the index substantially. ${ }^{9}$ The regional patterns of consolidation are described in the next subsections.

\footnotetext{
${ }^{7}$ Yoshitomi and Shirai (2001) note that commercial banks in Indonesia, the Republic of Korea, and Thailand are often owned by family businesses under family controlled conglomerates. Claessens, Djankov, and Lang (1999) document that smaller, as well as older, corporations in Asia are family-controlled. Family control is generally enhanced through pyramid structures, cross-shareholdings, and deviations from one-share-one-vote rules.

${ }^{8}$ Rajan and Zingales (1998) argue that, in the past, some Asian governments protected commercial banks by setting the maximum rate on deposits; when this policy was no longer feasible under deregulation and intensified competition, then governments protected banks through explicit or implicit guarantees and barriers to entry, increasing the banks' franchise value.

${ }^{9}$ See Cetorelli (1999) for examples of how the HH index varies with different patterns of large and small banks.
} 


\section{A. Asia}

While the number of banks fell substantially in the Asian crises countries included in Table 1, the level of concentration in their banking industries fell as well. The reduction in concentration is reflected in the decline of the share in total of deposits held by the three largest banks in each market, as well as by the decline in the HH indices-with the exception of Malaysia. The immediate task of crisis resolution in the Republic of Korea and Malaysia led to some degree of consolidation, but the authorities in both countries are pushing a second stage of reforms where consolidation plays a central role; consolidation has been slower in Thailand and the Philippines, where the process has been left more to market forces. ${ }^{10}$

In Korea, the authorities have taken an active role in the consolidation process and have recently initiated a second stage of financial restructuring with the enactment of a Financial Holding Company (FHC) Act. ${ }^{11}$ The first stage of financial restructuring had yielded substantial consolidation of the industry, bringing the number of banks to 17 by end1999 , down from 27 before the crisis. This stage was also accompanied by substantial downsizing and employment cuts. With the inclusion of the mergers announced so far as a result of the second stage, the $\mathrm{HH}$ index would increase by more than 200 points, to 838 (see Table 1). The main objectives of the FHC Act are to promote universal banking and to tackle the problem of overbanking, but the consolidation process is seen as increasingly dominated by employment considerations.

The Malaysian government had been trying to induce the consolidation of the banking system since the early 1990 s with limited success. The effects of the financial crisis of 1997-98, however-combined with the potential opening up of the financial services industry in the context of the forthcoming World Trade Organization (WTO) round of multilateral trade negotiations - -have led the authorities to take a more proactive role. The authorities have argued that, while the economic case for consolidation was clear, market forces alone were unable to bring about a significant degree of consolidation for a number of reasons. ${ }^{12}$ To jump-start the consolidation process, the government announced in July 1999 that 54 commercial banks, merchant banks, and finance companies would be consolidated into groups associated with six "anchor" banks. Bankers and investors took issue with the original plan and, in October 1999, the banks and finance companies were allowed to decide voluntarily with whom to merge. Ten core groups have emerged and largely completed the legal aspects of the mergers. The merger program now seems to be widely accepted among

\footnotetext{
${ }^{10}$ For a summary of consolidation progress in the cases of Philippines and Thailand, see BIS (2001).

${ }^{11}$ For more details, see BIS (2001).

${ }^{12}$ In particular, a number of medium and small-sized banks grew very fast before the crisis and emerged relatively unscathed from the crisis; this factor, combined with family and group-related ownership structures, made takeovers difficult to carry out (see IMF, 2001).
} 
Table 1. Number of Banks and Market Concentration in Selected Emerging Market Banking Systerns ${ }^{1}$

\begin{tabular}{|c|c|c|c|c|c|c|c|c|}
\hline \multirow[b]{3}{*}{ Country } & \multirow{3}{*}{$\begin{array}{c}\text { Number of Banks }{ }^{2} \\
1994 \\
\end{array}$} & \multicolumn{3}{|c|}{1994} & \multicolumn{4}{|c|}{2000} \\
\hline & & \multicolumn{2}{|c|}{ Share in Total Deposits (in percent) } & \multirow{2}{*}{$\begin{array}{c}\text { HH Index } \\
1994 \\
\end{array}$} & \multirow{2}{*}{$\begin{array}{c}\text { Number of Banks }{ }^{2} \\
2000 \\
\end{array}$} & \multicolumn{2}{|c|}{ Share in Total Deposits (in percent) } & \multirow{2}{*}{$\begin{array}{c}\text { HH Index } \\
2000 \\
\end{array}$} \\
\hline & & Largest 3 banks & Largest 10 banks & & & Largest 3 banks & Largest 10 banks & \\
\hline \multicolumn{9}{|l|}{ Asia } \\
\hline Republic of Korea ${ }^{3}$ & 30 & 52.8 & 86.9 & 1263.6 & 13 & 43.5 & 77.7 & 899.7 \\
\hline Malaysia & 25 & 44.7 & 78.3 & 918.9 & 10 & 43.4 & 82.2 & 1005.1 \\
\hline Philippines & 41 & 39.0 & 80.3 & 819.7 & 27 & 39.6 & 73.3 & 789.9 \\
\hline Thailand & 15 & 47.5 & 83.5 & 1031.7 & 13 & 41.7 & 79.4 & 854.4 \\
\hline \multicolumn{9}{|l|}{ Latin America } \\
\hline Argentina & 206 & 39.1 & 73.1 & 756.9 & 113 & 39.8 & 80.7 & 865.7 \\
\hline Brazil & 245 & 49.9 & 78.8 & 1220.9 & 193 & 55.2 & 85.6 & 1278.6 \\
\hline Chile & 37 & 39.5 & 79.1 & 830.4 & 29 & 39.5 & 82.0 & 857.9 \\
\hline Mexico & 36 & 48.3 & 80.8 & 1005.4 & 23 & 56.3 & 94.5 & 1360.5 \\
\hline Venezuela & 43 & 43.9 & 78.6 & 979.2 & 42 & 46.7 & 75.7 & 923.1 \\
\hline \multicolumn{9}{|l|}{ Central Europe } \\
\hline Czech Republic & 55 & 72.0 & 97.0 & 2101.5 & 42 & 69.7 & 90.3 & 1757.8 \\
\hline Hungary & 40 & 57.9 & 84.7 & 1578.8 & 39 & 51.5 & 80.7 & 1241.2 \\
\hline Poland & 82 & 52.8 & 86.9 & 1263.6 & 77 & 43.5 & 77.7 & 899.7 \\
\hline Turkey & 72 & 40.7 & 79.1 & 957.2 & 79 & 35.9 & 72.0 & 710.2 \\
\hline
\end{tabular}

Source: Staff estimates based on data from Fitch IBCA's BankScope and official data.

'Analysis is based on data available as of end-2000 for the largest thirty banks in a specific country, including M\&As; data on deposits are as of end-1999 or most

recent available in Fitch IBCA's BankScope.

${ }^{2}$ The number of banks is based on official data provided by country authorities, the OECD, or Fitch IBCA. In Asia, the total number of banks in a specific country includes only domestic commercial banks.

${ }^{3}$ Includes the merger between Kookmin and Housing \& Commercial Bank, as well as the merger between Shinhan and Cheju Bank. 
participants ${ }^{13}$ and some of them believe that the "shock" derived from the somewhat extreme early plan was useful to kick-start the process. However, further consolidation is likely. Indeed, Table 1 suggests that, despite the large fall in the number of banks, the $\mathrm{HH}$ index increased by a small margin, to just above 1,000 .

\section{B. Latin America}

The process of bank consolidation is more advanced in Latin America, as a result of the earlier occurrence of crises and foreign bank entry. The number of banks has fallen in all of the major countries (Table 1), especially in Argentina and Brazil, and this reduction was associated with increased concentration - as measured by both, the share in total deposits of the largest banks and the $\mathrm{HH}$ Indices. Although there was substantial government involvement in bank consolidation in the aftermath of crises, the latter part of the $1990 \mathrm{~s}$ shows a relatively larger role of market-driven transactions.

The role of the public and private sectors in the consolidation process is best exemplified in the cases of Argentina and Brazil. In both countries, the authorities carried through a process of guided consolidation that has dramatically reduced the number of banks. The widely praised approaches followed by both central banks during the 1990 s involved separating troubled banks into good and bad banks and selling the former with the aid of subsidized loans. ${ }^{14}$ The authorities also used moral suasion to persuade acquirers of failed banks to keep as much personnel as possible, but note that this was not a major issue because of the small size of the failed institutions. But the consolidation process was not just driven by the privatization and restructuring processes: at least 37 M\&A transactions involving private sector financial institutions occurred in Brazil between end-1995 and end-2000. ${ }^{15}$ Several of these transactions were driven by the three largest domestic private banks' attempts to remain competitive in the main regions of the country, as well as the perception by many medium and small banks that they would not be able to sustain positive earnings in such a competitive environment, especially in the wake of a few large foreign acquisitions. In Argentina, the five largest private banks have been the major winners of the consolidation process and they have increased their market share by more than 10 percentage points (from 31.8 to 42.3 percent) through a combination of organic growth and acquisitions. The size and scope of the current banking crisis in Argentina will certainly entail a government-driven consolidation process.

${ }^{13}$ The objectives of the Malaysian authorities were clarified with the publication, in March 2001, of a Financial Sector Master Plan (FSMP). The FSMP charts the future direction of the financial sector for the next 10 years and states that the main objective of the first phase is to develop a core set of strong domestic banking institutions, to be followed by a phase that levels the playing field with the incumbent foreign players and a final one that allows further foreign competition (see Bank Negara Malaysia, 2001).

${ }^{14}$ See also Peek and Rosengren (2000).

${ }^{15}$ See Abut, Bigio, and Mullen (2000). 
Chile's banking system has undergone a gradual but steady process of consolidation that has accelerated recently. ${ }^{16}$ The merger in Spain of Banco Santander and Banco Central Hispano in 1999, meant that the resulting institution (BSCH) acquired control of the two largest banks in Chile (Santiago and Santander) that jointly had a deposit market share of around 27 percent. This agreement set off an intense congressional debate over the potential damage to Chilean banking competition resulting from the concentration of more than a onefourth of the system loans and assets under a single financial group. The HH index in Table 1 does not show an important increase by end-2000 as the two institutions have not technically been merged and continue to operate as individual entities. If their balance sheets were to be combined, however, the HH index would reach around $1,235 .{ }^{17}$ The competitive balance of the industry has been enhanced by a more recent merger among two domestic institutions (Banco Edwards and Banco de Chile), that would bring the $\mathrm{HH}$ index to around 1,465.

In Mexico, the consolidation process is more advanced, and the three largest banks hold almost 60 percent of total deposits. The HH index increased by 355 points, from 1,005 in 1994 to 1,360 in 2000, the largest increase for all Latin American banking systems covered in Table 1. ${ }^{18}$ This increased concentration is due mostly to the sale of the second and third largest banks to the two largest Spanish banks, which are currently merging previous acquisitions in the country with the larger banks acquired after $1999 .{ }^{19}$ Indeed, BBVABancomer is the result of the consolidation of six banks that existed in 1994 (Naranjo, 2000). The sale of Bancomer to the Spanish group Banco Bilbao Vizcaya Argentaria (BBVA), together with that of Brazil's Banco Real to ABN-Amro, were considered hallmarks of the demise of dominant family ownership in Latin American banking systems. ${ }^{20}$ There was also consolidation among the local banks, as exemplified by the strong organic growth and acquisitions of Banorte, which increased its market share from 2.5 percent of total deposits in 1994 to 7.1 percent in 2000 . Notably, the sharp fall in employment in the banking sector in Mexico (from 126,852 employees in December 1994 to 90,198 by September 2000 -a

${ }^{16}$ See also BIS (2001).

${ }^{17}$ See Abut, Bigio, and Mullen (2001).

${ }^{18}$ Abut, Biggio, and Siller (2000a) and Abut, Biggio, and Mullen (2001) show somewhat higher figures for the $\mathrm{HH}$ indices, a result of a different sample of banks and different accounting conventions, but their results suggest the same qualitative pattern. As was noted in IMF (2000), Fitch IBCA makes an effort to adjust individual bank accounts for differences in reporting and accounting standards, and puts the accounts into a standardized global format.

${ }^{19}$ The more recent acquisition of Banamex by Citigroup will further increase the degree of concentration.

${ }^{20}$ See Vansetti, Guarco, and Bauer (2000). Goldberg, Dages, and Kinney (2000) offer an interesting investigation of the lending behavior of foreign banks in Mexico and Argentina. 
29 percent decline) was met with little resistance, in part owing to the protracted nature of the restructuring and consolidation process. The fall in employment is still less than the decline in lending activities and bankers have announced that more staff cuts are likely to follow. Some further consolidation can be expected, albeit at a smaller scale and concentrated among a few second-tier banks.

\section{Central Europe}

The major banking systems in Central Europe were much more concentrated than those of other emerging markets in the early $1990 \mathrm{~s}$, and the second half of the decade saw a reduction in concentration. Several factors explain this evolution from a high level of concentration (when $\mathrm{HH}$ indices for the three transition countries were above the 1,200 level) toward a less concentrated industry (with declines of more than 300 points in the $\mathrm{HH}$ indices, see Table 1). First, there was the legacy from the pre-market-reform era, namely large, stateowned savings banks concentrating a large share of deposits. Second, all three countries pursued liberal entry policies and a large number of banks entered the markets in the first half of the 1990s. Although entry policies were tightened significantly in the wake of difficulties experienced by some private banks by the mid-1990s (especially in the Czech Republic) several of the new entrants remained and gained market share from the larger, inefficient state-owned banks. Third, the state-owned banks suffered a sharp reduction in market share partly as a result of clean-up operations before their privatization to strategic (and mostly foreign) investors in the second half of the $1990 \mathrm{~s}$.

A consolidation trend has gradually begun to take hold in the region from 2000 . Although the region is underbanked in terms of banking assets and deposits, the number of banks is quite high (see Table 1). The consolidation trend is being driven by stronger banks being forced to absorb weaker ones to ensure continued stability, by shareholders that decide to exit the market, and by mergers of the parent companies of a large number of the foreign banks that are established in the region. The year 2000 saw examples of each of these developments. The takeover of Investicni a Postovni Banka (IPB) by Ceskoslovenska obchodni banka (CSOB) in the Czech Republic - an example of the first phenomenon ${ }^{21}$ catapulted the former trade bank to the leading position with almost 30 percent of bank deposits. As a result of a major rationalization of its global network, Dutch giant ABN-Amro decided to exit the Hungarian market and sold its retail operation to Kereskedelmi es Hitelbank (K\&H), which became the second-largest bank behind the dominant OTP (The National Savings and Commercial Bank of Hungary). Finally, the merger between Germany's HypoVereinsbank and Bank Austria, two foreign banks with a large presence in the region, is driving the consolidation of their respective Polish banks subsidiaries.

\footnotetext{
${ }^{21}$ A controlling interest in IPB was sold to Nomura Securities in 1998. However, Nomura reportedly regarded its stake in IPB as a portfolio investment and, apart from the sale of IPB's stronger assets, engaged in little restructuring of the bank. As IPB's performance continued to deteriorate, a "quiet" run on its deposits began (its deposits declined by about 50 percent in the first half of 2000) and the Czech National Bank (CNB) was forced to intervene in order to prevent a systemic crisis.
} 
The banking system in Turkey was highly fragmented as of end-2000, but this is changing as the resolution of the current banking crisis takes hold. The HH index is the lowest in the sample of countries considered in Table 1 and it has fallen since 1994 as a result of both a decline in the position of the four large state-owned banks and the rapid increase in the number of medium- and small-sized private banks. The number of private banks increased from 72 in $1995^{22}$ to 79 in 1999 . Since then, the number of banks has declined substantially with the resolution of the current crisis.

In sum, the reduction in the number of banks in the major emerging markets does not seem to have consistently translated into an increase in market concentration, as measured by traditional indicators. Nevertheless, the more important question concerns the extent to which competitive conditions have been affected by consolidation. Has bank market power increased? The view that market concentration is directly linked to competitive conduct is referred to as the "structure-conduct-performance" paradigm. ${ }^{23}$ In principle, however, there is no one-to-one relationship between market concentration and the degree of competition. For example, in the extreme case of a "contestable" market with no barriers to entry, even in highly concentrated markets, banks would not be able to exploit market power due to the threat of potential competition. ${ }^{24}$ Some of the same forces promoting consolidation in emerging markets, such as increased foreign bank entry, are also likely to have fostered competition. $^{25}$ Therefore, the next section moves beyond the largely descriptive approach followed so far and uses an econometric method to assess changes in competitive conditions.

\section{ECONOMETRIC METHODOLOGY}

In order to carry out a quantitative assessment of changes in market structure in the banking sectors of these countries, we conduct a test based on reduced form revenue functions proposed by Panzar and Rosse (1987). Panzar and Rosse show that the sum of the elasticities of a firm's revenue with respect to the firm's input prices (the so-called $H$ statistic) can be used to identify the nature of the market structure in which the firm operates. In long-run competitive equilibrium, the $H$ statistic should be equal to one, since any increase in input prices should lead to a one-to-one increase in total revenues. This is true since those firms that cannot cover their increase in input prices will be forced to exit the market. The same argument applies if the firm operates as a monopolist in a perfectly contestable market.

\footnotetext{
${ }^{22}$ There were 55 applications (mainly from industrial groups) pending approval by the Treasury at end-1995, but only a few were approved (see Fitch IBCA, 1996).

${ }^{23}$ See, for instance, Cetorelli (1999).

${ }^{24}$ See Baumol, Panzar, and Willig (1982) and Tirole (1988), p.309. For a different argument on why regulation-induced higher concentration could yield more intense competition, see Schargrodsky and Sturzenegger (2000).

${ }^{25}$ See Claessens, Demirgüç-Kunt, and Huizinga (2001).
} 
By contrast, $H$ will be negative if the firm operates as a monopoly-an upward shift in the marginal cost curve will be associated with a reduction in revenue as a result of the optimality condition for the monopolist. If the market structure is characterized by monopolistic competition, the $H$ statistic will lie between zero and one. If the elasticity of demand is constant, then there is a monotone relationship between the mark-up over marginal costs and the $H$ index.

More formally, letting $\mathrm{R}$ denote a revenue function of input prices $\mathrm{w}$ and exogenous variables $\mathrm{z}$ that shift the firm's revenue function:

$$
\begin{aligned}
& R=R(w, z) \\
& H=\sum_{i} \frac{\partial R^{*}}{\partial w_{i}} \frac{w_{i}}{R_{i}}
\end{aligned}
$$

\begin{tabular}{|l|l|}
\hline \multicolumn{2}{|c|}{ Table 2. Panzar and Rosse's $H$ Statistic } \\
\hline $\mathrm{H}<0$ & Market structure \\
\hline $0<\mathrm{H}<1$ & $\begin{array}{l}\text { Monopoly [or conjectural variation } \\
\text { oligopoly] }\end{array}$ \\
\hline $\mathrm{H}=1$ & Monopolistic competition \\
\hline & $\begin{array}{l}\text { Perfect competition or monopoly in a } \\
\text { perfectly contestable market }\end{array}$ \\
\hline
\end{tabular}

Various assumptions need to be made to apply this framework in our context. First, one needs to assume that banks can be treated as single product firms, acting exclusively as financial intermediaries (De Bandt and Davis, 2000). Banks produce interest revenues using labor, capital and intermediated funds (mainly deposits) as inputs. This assumption, while widely used in the literature, is of course controversial. ${ }^{26}$ Second, one needs to assume that higher input prices are not associated with higher quality services that generate higher revenues, since such a correlation may bias the computed $H$ statistic. This means, however, that if one rejects the hypothesis of a contestable/competitive market, this bias cannot be too large (Molyneux, Thornton and Lloyd-Williams, 1996). A third, and possibly less innocuous assumption, given the volatile economic environment in the economies we are studying, is that one needs to be observing banks in long-run equilibrium. As discussed below, we try to overcome this problem by using a panel data specification. Moreover, the problem might be less severe if we are mainly interested in changes in the $H$ measure over time. In other words, the hope is that, even if we cannot assess with certainty whether at any point in time the market structure in the countries studies falls into one of the three categories, we will still be

\footnotetext{
${ }^{26}$ Note however, that product differentiation is allowed for in the monopolistic competition model.
} 
able to infer the direction of change in market structure by testing for changes in the $H$ values over time. $^{27}$

The Panzar and Rosse (1987) approach has been applied widely to the analysis of mature banking systems. Early studies examine competitive conditions in the U.S. and Canada (see Shaffer (1989) and Nathan and Neave (1989), respectively.) Later work has focused on European economies. ${ }^{28}$

To derive the $H$ statistic, we estimate the following reduced form revenue equation:

$$
\ln \frac{I R}{c a p}=c+a \cdot \ln w_{L}+b \cdot \ln w_{F}+c \cdot \ln w_{K}+d \cdot o t h
$$

where

$I R \quad=\quad$ interest revenue (or interest revenue divided by total assets)

$C=$ constant

$w_{L}=$ unit price of labor

$w_{F}=$ unit price of funds

$w_{X}=$ unit price of capital

cap $=$ capacity indicators, such as total fixed assets

oth = other factors potentially affecting interest revenues, such as the business mix of the bank and the size of nonperforming loans

This specification is similar to the ones used in other studies. Following De Band and Davis, we include the ratio of loans to total assets as an explanatory variable in order to control to some extent for differences in the banks" "production function." Alternatively, we also estimate an equation for unscaled interest revenue, where we control for size effects on the right-hand side.

$$
\ln I R=c+a \cdot \ln w_{L}+b \cdot \ln w_{F}+c \cdot \ln w_{K}+d \cdot c a p+e \cdot o t h
$$

${ }^{27}$ Further assumptions include profit maximization and normally shaped revenue and cost functions.

${ }^{28}$ For studies of European countries, see Molyneux, Lloyd-Williams, and Thornton (1994), Bikker and Groeneveld, (2000), and De Bandt and Davies, (2000). Individual country studies have examined banking markets in Austria (Mooslechner and Schnitzer, 1995), Italy (Coccorese, 1998), Switzerland (Rime, 1999), Germany (Lang, 1997, and Hempell, 2002), Japan (Molyneux, Lloyd-Williams, and Thornton, 1996), and Finland (Vesala, 1995). The only study based on this methodology of an emerging market that we are aware of is Feyzioglu and Gelos (2000), which examines the case of Bulgaria. 
In contrast to most of the literature, we do not rely on a simple cross-sectional estimation, but carry out a panel estimation with fixed effects, allowing the coefficients on the unit input prices to change over time. ${ }^{29}$ This approach has various advantages. First, by including bank fixed effects, we can control for unobserved heterogeneity-this is important since the regressions are otherwise likely to suffer from omitted variable problems. All bankspecific, non time-varying determinants of revenues not explicitly addressed in the regression specification are captured by the fixed effects. Second, as noted above, a panel estimation allows us to obtain more reliable estimates by observing the behavior of banks over time and testing for changes in the coefficients. This test is implemented by dividing the period 1994 99 into two sub-periods and interacting the input price variables (lnwl, lnwf, and lnwk) with a dummy variable that takes the value of one in the second sub-period. If the interaction term yields significant estimates, they indicate a structural break in the statistical relationship between input prices and revenues, and we can ascertain if and in which direction the sum of the elasticities changed.

Depending on the country, we chose either 1997 or 1998 as the year marking the structural break. In the case of Argentina, Brazil, Chile, and Hungary we chose 1997 as the year of the structural break since these countries began the consolidation process somewhat earlier than the other countries, for which we let 1998 mark the break year. The main broad conclusions drawn from the estimations are not affected by this choice.

\section{DATA}

Data were obtained from the Fitch-IBCA Ltd Bankscope CD Rom. The sample covers 126 banks in the case of Argentina, 189 banks for Brazil, 37 for Chile, 33 for the Czech Republic, 72 institutions for Mexico, 55 for Hungary, 55 for Poland and 69 in the Turkish case. ${ }^{30}$ However, coverage of individual variables varies over time. Table 3 provides some summary statistics.

A feature of the Fitch IBCA database is that it does not provide a complete historical panel of banks over time. For example, if a merger occurs, only the largest of the merged banks is typically kept retroactively in the database. Similarly, exiting banks are deleted fully from the database. However, we believe that the bias this feature of the database introduces is not problematic for our case. In fact, as mentioned earlier, applying the methodology proposed by Panzar and Rosse presupposes that banks have reached their steady state, and the inclusion of new entrants or banks that went bankrupt would therefore be problematic from that perspective.

${ }^{29}$ An exception is de Band and Davis (2000).

${ }^{30}$ The severe balance sheet impairment and negative revenues of the Asian crisis countries prevented their inclusion in the regression analysis of this section. 


\begin{tabular}{|c|c|c|c|c|c|c|c|c|c|}
\hline \multicolumn{10}{|c|}{ Table 3. Descriptive Bank Statistics } \\
\hline & Total Assets & $\begin{array}{c}\text { Interest } \\
\text { Revenues }\end{array}$ & $\begin{array}{c}\text { Personnel } \\
\text { Expenses } \\
\text { /(Deposits+ } \\
\text { Loans) }\end{array}$ & $\begin{array}{c}\text { Interest } \\
\text { Costs }\end{array}$ & $\begin{array}{c}\text { Other } \\
\text { Operating } \\
\text { Costs }\end{array}$ & Equity & $\begin{array}{l}\text { Fixed } \\
\text { Assets }\end{array}$ & $\begin{array}{l}\text { Loans/ } \\
\text { Assets }\end{array}$ & Deposits \\
\hline Argentina & $\begin{array}{c}1,233 \\
(3,492)\end{array}$ & $\begin{array}{c}94 \\
(185)\end{array}$ & $\begin{array}{c}.032 \\
(.046) \\
\end{array}$ & $\begin{array}{c}45 \\
(96) \\
\end{array}$ & $\begin{array}{l}38 \\
(58)\end{array}$ & $\begin{array}{l}1,469 \\
(401)\end{array}$ & $\begin{array}{c}38 \\
(81) \\
\end{array}$ & $\begin{array}{c}53 \\
(.18)\end{array}$ & $\begin{array}{c}788 \\
(1,842)\end{array}$ \\
\hline Brazil & $\begin{array}{c}4,488 \\
(1,670)\end{array}$ & $\begin{array}{c}725 \\
(3,482)\end{array}$ & $\begin{array}{c}.096 \\
(0.58) \\
\end{array}$ & $\begin{array}{c}558 \\
(3,189) \\
\end{array}$ & $\begin{array}{c}208 \\
(2,494)\end{array}$ & $\begin{array}{c}351 \\
(1,068)\end{array}$ & $\begin{array}{c}87 \\
(355)\end{array}$ & $\begin{array}{c}.37 \\
(.20)\end{array}$ & $\begin{array}{c}2,059 \\
(8,426)\end{array}$ \\
\hline Chile & $\begin{array}{c}2,663 \\
(5,677)\end{array}$ & $\begin{array}{c}253 \\
(365)\end{array}$ & $\begin{array}{c}.018 \\
(.014)\end{array}$ & $\begin{array}{c}183 \\
(328)\end{array}$ & $\begin{array}{c}26 \\
(32)\end{array}$ & $\begin{array}{c}141 \\
(299)\end{array}$ & $\begin{array}{c}45 \\
(64)\end{array}$ & $\begin{array}{c}.56 \\
(.23)\end{array}$ & $\begin{array}{c}1,406 \\
(1,959)\end{array}$ \\
\hline $\begin{array}{l}\text { Czech } \\
\text { Republic }\end{array}$ & $\begin{array}{c}2,758 \\
(4,752)\end{array}$ & $\begin{array}{c}240 \\
(405)\end{array}$ & $\begin{array}{c}.010 \\
(.016)\end{array}$ & $\begin{array}{c}172 \\
(293)\end{array}$ & $\begin{array}{c}11 \\
(47)\end{array}$ & $\begin{array}{c}167 \\
(308)\end{array}$ & $\begin{array}{c}78 \\
(154)\end{array}$ & $\begin{array}{c}.40 \\
(.19)\end{array}$ & $\begin{array}{c}2,150 \\
(3,587)\end{array}$ \\
\hline Hungary & $\begin{array}{c}1,926 \\
(5,687)\end{array}$ & $\begin{array}{c}215 \\
(510)\end{array}$ & $\begin{array}{c}.020 \\
(.041)\end{array}$ & $\begin{array}{c}180 \\
(506)\end{array}$ & $\begin{array}{c}48 \\
(111)\end{array}$ & $\begin{array}{c}77 \\
(103)\end{array}$ & $\begin{array}{c}31 \\
(57)\end{array}$ & $\begin{array}{c}.39 \\
(.16)\end{array}$ & $\begin{array}{c}920 \\
(1,556)\end{array}$ \\
\hline Mexico & $\begin{array}{c}6,029 \\
(1,010)\end{array}$ & $\begin{array}{c}1,020 \\
(1,634)\end{array}$ & $\begin{array}{l}.034 \\
(.12) \\
\end{array}$ & $\begin{array}{c}802 \\
(1,258) \\
\end{array}$ & $\begin{array}{c}38 \\
(198)\end{array}$ & $\begin{array}{c}408 \\
(761)\end{array}$ & $\begin{array}{c}117 \\
(243)\end{array}$ & $\begin{array}{c}.57 \\
(.24) \\
\end{array}$ & $\begin{array}{c}4,312 \\
(7,039)\end{array}$ \\
\hline Poland & $\begin{array}{c}2,000 \\
(4,985)\end{array}$ & $\begin{array}{c}179 \\
(326)\end{array}$ & $\begin{array}{c}.092 \\
(1.05)\end{array}$ & $\begin{array}{c}119 \\
(228)\end{array}$ & $\begin{array}{c}7 \\
(28)\end{array}$ & $\begin{array}{c}220 \\
(893) \\
\end{array}$ & $\begin{array}{c}40 \\
(65) \\
\end{array}$ & $\begin{array}{c}.41 \\
(.17)\end{array}$ & $\begin{array}{c}1,192 \\
(2,180)\end{array}$ \\
\hline Turkey & $\begin{array}{c}2,288 \\
(5,180)\end{array}$ & $\begin{array}{c}514 \\
(1,040)\end{array}$ & $\begin{array}{c}.031 \\
(.043)\end{array}$ & $\begin{array}{c}384 \\
(902)\end{array}$ & $\begin{array}{c}62 \\
(159)\end{array}$ & $\begin{array}{c}139 \\
(267)\end{array}$ & $\begin{array}{c}55 \\
(127)\end{array}$ & $\begin{array}{c}.37 \\
(.20)\end{array}$ & $\begin{array}{c}1,666 \\
(3,515)\end{array}$ \\
\hline
\end{tabular}

Another possible source of bias, as De Bandt and Davis (2000) point out, stems from the fact that only the more prominent banks are included in the database, excluding smaller ones which potentially might have more market power in local markets. The Fitch-IBCA database contains frequent missing observations for some variables, such as the number of bank employees.

As we do not have exact data on unit factor prices, we approximate them in the following way: ${ }^{31}$

$\mathrm{w}_{\mathrm{L}}=$ Personnel expenses/(deposits+loans)

or $^{32}$ personnel expenses/(total assets)

${ }^{31}$ For similar definition of variables, see de Bandt and Davis (2000), Molyneux, LloydWilliams and Thornton (1994), Molyneux, Thornton and Lloyd-Williams (1996), Nathan and Neave (1989), Rime (1999), and Shaffer (1982).

${ }^{32}$ It would have been preferable to use the number of employees in the denominator.

However, the Fitch IBCA data for this variable is very scant, and we were not able to collect comprehensive time series from other sources, except for the case of Poland, and, to a more limited extent, Argentina. 


$\begin{array}{ll}\mathrm{w}_{\mathrm{F}}= & \text { Interest expenses/(deposits+interbank time and demand deposits), } \\ \mathrm{w}_{\mathrm{K}} & =\text { Other expenses/fixed assets } \\ \text { cap } & =\quad \text { Logarithm of total assets } \\ \mathrm{bm} & =\quad \text { Total loans/total assets }\end{array}$

\section{RESULTS}

The econometric results suggest that for most countries, market structure can be characterized by monopolistic competition, a result also observed in many mature markets. ${ }^{34}$ Table 4 shows the results from fixed-effects estimations of equation (2) for each country, the derived $H$ statistics and corresponding tests. In most cases, the estimated coefficients have the expected signs and are statistically significant at the 5 percent level. The $H$-statistics are always between zero and one, indicating either monopolistic competition or inconclusive results. For Argentina and Hungary, the $H$ statistic is compatible with either monopolistic or perfect competition.

Competitive conditions over the period 1994-99 worsened in only one of the eight emerging markets examined, while constancy of the $H$ statistic in the other cases. For Turkey, we cannot reject a decline in the $H$ statistic, suggesting that competition has become less intense since 1998. Interestingly, while we cannot reject constancy of the $H$ statistic for Argentina, competition seems to have increased in the later years of the sample. This is consistent with the results of Burdisso, Catena and d'Amato (2001) who find that competitive conditions in Argentina during 1997-99 were very close to perfect competition.

These results are largely in line with the simple statistics presented earlier. The share in total deposits of the largest banks and the $\mathrm{HH}$ indices decreased in Central Europe, and consistent with these numbers, we do not find a decrease in the $H$ statistic for these countries. For Latin America, while Brazil and Chile showed moderate increases in the large banks' shares and the HH indices, the econometric results do not reject constancy of the $H$ statistic. $^{35}$

\footnotetext{
${ }^{33}$ There was not enough information available on other liabilities such as subordinated debt or long-term borrowing.

${ }^{34}$ See, for example, De Bandt and Davis (2000).

${ }^{35}$ The results for Brazil are in line with the findings by Nakane (2001), who, using a different methodology, concludes that Brazilian banks do have some market power and that neither perfect competition nor monopoly accurately describes the competitive conditions of the Brazilian banning market.
} 


\begin{tabular}{|c|c|c|c|c|c|c|c|c|}
\hline \multicolumn{9}{|c|}{ Table 4. Fixed-Effects Estimation of Revenue Equation (2) } \\
\hline & $\begin{array}{c}\text { Argent } \\
\text { ina }\end{array}$ & Brazil & Chile & $\begin{array}{c}\text { Czech } \\
\text { Republic }\end{array}$ & Hungary & Mexico & Poland & Turkey \\
\hline In $w^{T}$ & $\begin{array}{c}0.22 \\
(2.58)\end{array}$ & $\begin{array}{c}0.23 \\
(4.20)\end{array}$ & $\begin{array}{c}0 . \overline{29} \\
(4.91)\end{array}$ & $\begin{array}{c}0.37 \\
(4.81)\end{array}$ & $\begin{array}{c}0.37 \\
(2.52)\end{array}$ & $\begin{array}{c}0.12 \\
(2.17)\end{array}$ & $\begin{array}{c}0.23 \\
(3.18)\end{array}$ & $\begin{array}{c}0.32 \\
(4.01)\end{array}$ \\
\hline $\ln w^{f}$ & $\begin{array}{c}0.42 \\
(5.25)\end{array}$ & $\begin{array}{c}0.36 \\
(7.55)\end{array}$ & $\begin{array}{c}0 . \overline{46} \\
(10.21)\end{array}$ & $\begin{array}{c}0.26 \\
(5.07)\end{array}$ & $\begin{array}{c}0.37 \\
(2.73)\end{array}$ & $\begin{array}{c}0.33 \\
(2.21)\end{array}$ & $\begin{array}{c}0.31 \\
(2.96)\end{array}$ & $\begin{array}{c}0.11 \\
(2.19)\end{array}$ \\
\hline $\ln w^{k}$ & $\begin{array}{c}0.19 \\
(2.29)\end{array}$ & $\begin{array}{c}0.08 \\
(3.52)\end{array}$ & $\begin{array}{c}0.02 \\
(0.53)\end{array}$ & $\begin{array}{c}-0.04 \\
(-1.89)\end{array}$ & $\begin{array}{c}0.09 \\
(1.45)\end{array}$ & $\begin{array}{c}0.05 \\
(1.25)\end{array}$ & $\begin{array}{c}0.01 \\
(0.62)\end{array}$ & $\begin{array}{c}0.15 \\
(3.23)\end{array}$ \\
\hline $\begin{array}{l}\ln w^{\text {T* }} \\
\mathrm{D} \text { (after) }\end{array}$ & $\begin{array}{c}0.13 \\
(2.43)\end{array}$ & $\begin{array}{c}0.04 \\
(2.89)\end{array}$ & $\begin{array}{c}0.03 \\
(1.50)\end{array}$ & $\begin{array}{c}-0.06 \\
(-1.60)\end{array}$ & $\begin{array}{c}-0.04 \\
(-0.93)\end{array}$ & $\begin{array}{c}-0.08 \\
(-2.17)\end{array}$ & $\begin{array}{c}0.05 \\
(0.76)\end{array}$ & $\begin{array}{c}-0.03 \\
(1.58)\end{array}$ \\
\hline $\begin{array}{l}\ln w * \\
\mathrm{D} \text { (after) }\end{array}$ & $\begin{array}{c}-0.20 \\
(-2.93)\end{array}$ & $\begin{array}{c}-0.06 \\
(-1.46)\end{array}$ & $\begin{array}{c}-0.03 \\
(1.06)\end{array}$ & $\begin{array}{c}0.23 \\
(3.01)\end{array}$ & $\begin{array}{c}0.12 \\
(1.28)\end{array}$ & $\begin{array}{c}0.13 \\
(1.17)\end{array}$ & $\begin{array}{c}-0.05 \\
(-0.38)\end{array}$ & $\begin{array}{c}0.02 \\
(0.50)\end{array}$ \\
\hline $\begin{array}{l}\ln w^{k *} \\
D \text { (after) }\end{array}$ & $\begin{array}{c}0.20 \\
(1.88)\end{array}$ & $\begin{array}{c}0.03 \\
(1.41)\end{array}$ & $\begin{array}{c}-0.01 \\
(-0.55)\end{array}$ & $\begin{array}{c}-0.16 \\
(-2.73)\end{array}$ & $\begin{array}{c}-0.13 \\
(-1.53)\end{array}$ & $\begin{array}{c}-0.03 \\
(-0.76)\end{array}$ & $\begin{array}{c}-0.01 \\
(-0.50)\end{array}$ & $\begin{array}{c}-0.10 \\
(-2.76)\end{array}$ \\
\hline $\mathrm{bm}$ & $\begin{array}{c}1.32 \\
(3.92)\end{array}$ & $\begin{array}{c}0.60 \\
(3.89)\end{array}$ & $\begin{array}{c}0.25 \\
(2.11)\end{array}$ & $\begin{array}{c}-0.16 \\
(-0.55)\end{array}$ & $\begin{array}{c}0.49 \\
(1.10)\end{array}$ & $\begin{array}{c}0.79 \\
(4.03)\end{array}$ & $\begin{array}{c}-0.04 \\
(-0.27)\end{array}$ & $\begin{array}{c}-0.08 \\
(-0.42)\end{array}$ \\
\hline$H$ early & $\begin{array}{c}0.84 \\
(7.99)\end{array}$ & $\begin{array}{c}0.66 \\
(10.64)\end{array}$ & $\begin{array}{c}0.76 \\
(11.96)\end{array}$ & $\begin{array}{c}0.59 \\
(7.06)\end{array}$ & $\begin{array}{c}0.83 \\
(4.31)\end{array}$ & $\begin{array}{c}0.50 \\
(4.19)\end{array}$ & $\begin{array}{c}0.54 \\
(6.19)\end{array}$ & $\begin{array}{c}0.58 \\
(6.16)\end{array}$ \\
\hline $\begin{array}{l}\text { Market } \\
\text { Structure } \\
\text { early }\end{array}$ & $\begin{array}{c}\text { Inc. } \\
\text { (MC or } \\
\text { Perfect } \\
\text { Comp.) }\end{array}$ & $\overline{\mathrm{MC}}$ & $\overline{\mathrm{MC}}$ & $\overrightarrow{\mathrm{MC}}$ & $\begin{array}{l}\text { Inc. (MC or } \\
\text { Perfect } \\
\text { Comp.) }\end{array}$ & $\mathrm{MC}$ & $\mathrm{MC}$ & $\mathrm{MC}$ \\
\hline$H$ late & $\begin{array}{c}0.97 \\
(8.43)\end{array}$ & $\begin{array}{c}0.69 \\
(12.38)\end{array}$ & $\begin{array}{c}0.75 \\
(12.46)\end{array}$ & $\begin{array}{c}0.60 \\
(7.52)\end{array}$ & $\begin{array}{c}0.77 \\
(4.22)\end{array}$ & $\begin{array}{c}0.51 \\
(5.24)\end{array}$ & $\begin{array}{c}0.53 \\
(7.41)\end{array}$ & $\begin{array}{c}0.47 \\
(4.59)\end{array}$ \\
\hline $\begin{array}{l}\text { Market } \\
\text { Structure late }\end{array}$ & $\begin{array}{l}\text { Inc. } \\
\text { (MC or } \\
\text { Perfect } \\
\text { Comp.) }\end{array}$ & $\mathrm{MC}$ & $\mathrm{MC}$ & $\mathrm{MC}$ & $\begin{array}{c}\text { Inc. (MC or } \\
\text { Perfect } \\
\text { Comp.) }\end{array}$ & $\mathrm{MC}$ & $\overline{\mathrm{MC}}$ & $\mathrm{MC}$ \\
\hline $\begin{array}{l}\text { Test for } \\
\text { change in } H\end{array}$ & $\begin{array}{c}\text { Cannot } \\
\text { reject } \\
\text { constan } \\
\text { cy } \\
(p=0.1 \\
7)\end{array}$ & $\begin{array}{l}\text { Cannot } \\
\text { reject } \\
\text { constany } \\
(p=0.57)\end{array}$ & $\begin{array}{c}\text { Cannot } \\
\text { reject } \\
\text { constancy } \\
(p=0.52)\end{array}$ & $\begin{array}{l}\text { Cannot } \\
\text { reject } \\
\text { constancy } \\
(p=0.88)\end{array}$ & $\begin{array}{c}\text { Cannot } \\
\text { reject } \\
\text { constancy } \\
(p=0.57)\end{array}$ & $\begin{array}{c}\text { Cannot } \\
\text { reject } \\
\text { constancy } \\
(p=0.83)\end{array}$ & $\begin{array}{c}\text { Cannot } \\
\text { reject } \\
\text { constancy } \\
(p=0.87)\end{array}$ & $\begin{array}{c}\text { Cannot } \\
\text { reject } \\
\text { decline } \\
(p=0.01)\end{array}$ \\
\hline $\begin{array}{l}\text { Number of } \\
\text { observations }\end{array}$ & 211 & 752 & 197 & 103 & 77 & 186 & 190 & 254 \\
\hline$R^{2}$ (within) & 0.85 & 0.60 & 0.94 & 0.76 & 0.77 & 0.69 & 0.77 & 0.82 \\
\hline $\begin{array}{l}\text { Year of } \\
\text { structural } \\
\text { break }\end{array}$ & 1997 & 1997 & 1997 & 1998 & 1997 & 1998 & 1998 & 1998 \\
\hline $\begin{array}{l}\text { Note: Depend } \\
\text { reports the resu } \\
H^{\prime} \text { refers to tes } \\
\text { the } 5 \% \text { confide } \\
\text { at the } 2.5 \% \text { con } \\
\text { wl is defined as }\end{array}$ & $\begin{array}{l}\text { t variable } \\
\text { from pan } \\
\text { n wheth } \\
\text { level. " } \\
\text { ence leve } \\
\text { tal persor }\end{array}$ & $\begin{array}{l}\text { interest i } \\
\text { data reg } \\
\text { the H st: } \\
\text { C" (Mon } \\
\text { "Inc." ( } \\
\text { el expen }\end{array}$ & $\begin{array}{l}\text { e/total as } \\
\text { ons using } \\
\text { changed } \\
\text { stic Com } \\
\text { clusive) } \\
\text { ivided by }\end{array}$ & $\begin{array}{l}H \text { statisti } \\
\text { ly data or } \\
\text { e period } \\
\text { on) indic } \\
\text { tes that } t \\
\text { assets. } \mathrm{T}\end{array}$ & $\begin{array}{l}\text { e sum of th } \\
\text { vidual bank } \\
\text { ig with (and } \\
\text { lat the hypc } \\
\text { ults are con } \\
\text { orted stand }\end{array}$ & $\begin{array}{l}\text { ticities of } \\
\text { he period } \\
\text { ding) the } \\
\mathrm{s} \mathrm{H}>0 \text { and } \\
\text { le with va } \\
\text { rrors are ro }\end{array}$ & $\begin{array}{l}\text { st rate rev } \\
1999 . \text { "T } \\
\text { f the strus } \\
\text { could bot } \\
\text { types of } n \\
\text { Hubert/M }\end{array}$ & $\begin{array}{l}\text { s. The table } \\
\text { r change in } \\
\text { I break, at } \\
\text { be rejected } \\
\text { t structure. }\end{array}$ \\
\hline
\end{tabular}


The only countries for which the econometric results do not appear to be consistent with the statistics presented earlier are Mexico and Turkey. Mexico experienced both a rise in the share of the largest banks and an increase in the $\mathrm{HH}$ index, but the $H$ statistic remains constant. Turkey saw a decline in the share of large banks and in the $\mathrm{HH}$ index, while displaying a decrease in the $H$ statistic. The financial turbulence in Turkey at the beginning and end of our sample might account at least to some degree for this result.

\section{A. Robustness}

While individual results vary somewhat with the exact econometric specification, the main result - the rejection of the notion of a widespread worsening in competitive conditions across countries-always holds.

We first follow De Bandt and Davis (2000) in estimating an unscaled revenue equation as in eq. (3) and defining the unit price of labor as personnel expenses divided by total deposits and total loans (Appendix I). ${ }^{36}$ While this yields negative coefficients on the unit price of labor, the $H$ statistic remains between 0 and 1 in all but one case (Poland) for both sub-periods. Overall, according to the estimation results of this specification, the confidence bands for the $H$ statistics are more often compatible with two different forms of market structure than in the specification reported in Table 4. As previously, we are unable to reject the null hypothesis of no change in the $H$ statistic in most cases. The decline in competition intensity reported earlier is confirmed for the case of Turkey. In contrast to the results in Table 4, but consistent with the developments of market concentration discussed in the previous section, we also find a decline in competition for Mexico.

When including time dummies, the results suggest no change in competitive conditions for Argentina, Brazil, Mexico, and Poland, in line with the results presented earlier (Appendix I). However, the estimations with time effects indicate a worsening in competitive conditions in Chile and Hungary, while the result for Turkey disappears.

Finally, for two of the countries in our sample, Argentina and Poland, we are able to estimate equation (2) using personnel expenses divided by the number of employees as the proxy for unit labor costs (Appendix I). For Poland, while the coefficient on the unit price of labor becomes positive, the results continue to suggest a structure of monopolistic competition, without a change in the later years. For Argentina, data on the number of employees is available only starting 1997 . For this period, consistent with the results in Table 4, the confidence interval around the $H$ statistic does not allow us to distinguish between the market structures monopolistic competition or perfect competition. For Poland, the $H$ statistic obtained this way are somewhat higher than those presented in Table 4, and we cannot conclusively distinguish between monopolistic competition and perfect competition in neither sub period. However, consistent with the baseline results, we cannot reject constancy of the $H$ statistic over the entire sample period.

${ }^{36}$ De Bandt and Davis (2000) argue that deposits and loans represent the most laborintensive bank activities. 


\section{Competition and foreign bank participation}

The positive correlation between the $H$ statistics and measures of foreign bank participation supports the notion that foreign competition or the threat thereof has helped to maintain competitive pressures. If the opening to foreign competition has indeed attenuated any reductions in competition intensity resulting from consolidation, one should see a correlation between our measure of competition intensity - the $H$ statistics - and the degree of foreign bank participation. Here, we use measures of foreign control for 1994 and 1999 reported in the IMF's (2000) International Capital Markets report (Table 5). The level of foreign bank control increased substantially between 1994 and 1999 in all countries except Turkey - the only country for which we could not reject a decline in competive pressures in Table 4. Moreover, there is a clear positive correlation (0.43) between the $H$ statistics reported in Table 4 and the measures of foreign control, as shown in Figure 1. While the number of observations is low, these correlations are in line with findings reported by Claessens, Demirgüç-Kunt, and Huizinga (2001) that countries with a higher number of foreign banks reduces profits and overhead expenses of domestic banks.

\begin{tabular}{|l|c|c|}
\hline \multicolumn{3}{|c|}{ Table 5. Foreign Bank Participation } \\
\hline \multicolumn{1}{|c|}{ Country } & $\begin{array}{c}\text { Foreign Control } \\
1994\end{array}$ & $\begin{array}{c}\text { Foreign Control } \\
1999\end{array}$ \\
\hline Argentina & 17.9 & 48.6 \\
\hline Brazil & 8.4 & 16.8 \\
\hline Chile & 16.3 & 53.6 \\
\hline Czech Republic & 5.8 & 49.3 \\
\hline Hungary & 19.8 & 56.6 \\
\hline Mexico & 1.0 & 18.8 \\
\hline Poland & 2.1 & 52.8 \\
\hline Turkey & 2.7 & 1.7 \\
\hline Source: IMF (2000). Foreign control denotes the ratio of assets of banks where foreigners own more than \\
50 percent of total equity to total bank assets. \\
\hline
\end{tabular}


Figure 1. Foreign Control and $H$ Statistic

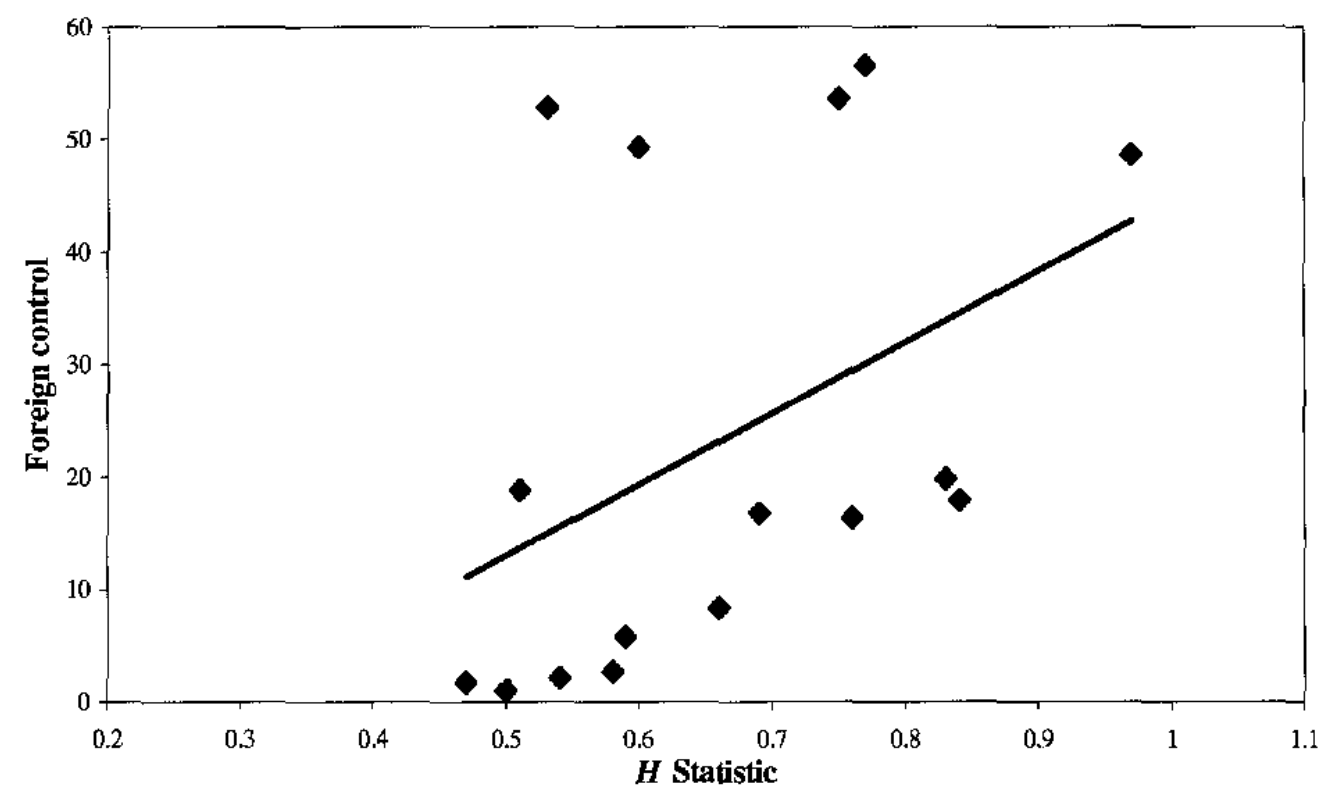

Note: $H$ statistics are those reported for the two sub-periods reported in Table 4. The $H$ statistics for the early sub-periods are plotted against the foreign control shares for 1994, the $\mathrm{H}$ statistics for the later sub-periods are plotted against the foreign control shares for 1999.

\section{Conclusions}

The process of consolidation in emerging market banking system has, to a large extent, not yet translated into a decline in competitive pressures. To some degree, this may be due to the fact that the process is yet in its infancy in some of the countries analyzed here, particularly in Central Europe and Turkey. Nevertheless, the results for two countries in which the consolidation process is more advanced, namely Argentina and Mexico, shows that the ultimate effect on competition intensity is by no means obvious. We do find support for the view that foreign bank competition has attenuated any decline in competition intensity stemming from consolidation.

However, one should not conclude that the potential for increases in market power is absent even if consolidation proceeds further in the emerging markets. In some instances, local authorities have already acted on preventing the creation of institutions that were perceived as too dominant, probably with good reasons. For example, the potential merger between the two largest Mexican banks--which would have created an institution with control over 40 percent of the system's deposits - raised concerns among the regulatory authorities and finally did not come through. Similarly, the control of the two largest Chilean banks (commanding 27 percent of deposits) by Spain's BSCH, prompted the authorities to 
modify the Banking Law and require authorization when a merger leads to the creation of an institution that controls more than 20 percent of deposits. ${ }^{37}$

Further examination of how consolidation and foreign bank participation is changing the financial services landscape in emerging markets, including the implications for prudential regulation, competition regulation, and macroeconomic policies, remains an important research field.

${ }^{37}$ See IMF 2001 for a more thorough discussion of policy issues associated to the consolidation process in emerging markets financial systems. 


\section{Alternative Econometric Specifications}

Using log of interest revenue (unscaled) as dependent variable and total personnel expenses divided by total loans and deposits as unit price of labor.

\begin{tabular}{|c|c|c|c|c|c|c|c|c|}
\hline & Argentina & $\underset{1}{\text { Brazi }}$ & Chile & $\begin{array}{c}\text { Czech } \\
\text { Republic }\end{array}$ & Hungary & Mexico & Poland & Turkey \\
\hline $\ln w^{\prime}$ & $\begin{array}{c}-0.53 \\
(-3.85)\end{array}$ & $\begin{array}{c}-0.32 \\
(-5.65)\end{array}$ & $\begin{array}{c}-0.47 \\
(-5.59)\end{array}$ & $\begin{array}{c}-0.21 \\
(-1.64)\end{array}$ & $\begin{array}{c}-0.26 \\
(-1.63)\end{array}$ & $\begin{array}{c}-0.25 \\
(-2.06)\end{array}$ & $\begin{array}{c}-0.64 \\
(-6.91)\end{array}$ & $\begin{array}{c}-0.46 \\
(-4.74)\end{array}$ \\
\hline $\ln w^{f}$ & $\begin{array}{c}0.46 \\
(3.00)\end{array}$ & $\begin{array}{c}0.40 \\
(7.52)\end{array}$ & $\begin{array}{c}0.47 \\
(6.07)\end{array}$ & $\begin{array}{c}0.33 \\
(2.85)\end{array}$ & $\begin{array}{c}0.46 \\
(3.24)\end{array}$ & $\begin{array}{c}0.39 \\
(1.98)\end{array}$ & $\begin{array}{c}0.55 \\
(6.94)\end{array}$ & $\begin{array}{c}0.23 \\
(2.86)\end{array}$ \\
\hline $\ln w^{k}$ & $\begin{array}{c}0.88 \\
(6.58)\end{array}$ & $\begin{array}{c}0.20 \\
(5.73)\end{array}$ & $\begin{array}{c}0.34 \\
(3.63)\end{array}$ & $\begin{array}{c}-0.08 \\
(-1.59)\end{array}$ & $\begin{array}{c}0.33 \\
(1.96)\end{array}$ & $\begin{array}{c}0.29 \\
(4.05)\end{array}$ & $\begin{array}{c}0.05 \\
(1.68)\end{array}$ & $\begin{array}{c}0.51 \\
(5.11)\end{array}$ \\
\hline $\begin{array}{l}\ln w^{2} \\
D \text { (after) }\end{array}$ & $\begin{array}{c}0.08 \\
(0.72)\end{array}$ & $\begin{array}{c}0.02 \\
(1.33)\end{array}$ & $\begin{array}{c}0.00 \\
(0.01)\end{array}$ & $\begin{array}{c}-0.05 \\
(-1.11)\end{array}$ & $\begin{array}{c}-0.04 \\
(-0.77)\end{array}$ & $\begin{array}{c}0.04 \\
(0.56)\end{array}$ & $\begin{array}{c}-0.10 \\
(-1.16)\end{array}$ & $\begin{array}{l}-0.08 \\
(-2.98)\end{array}$ \\
\hline $\begin{array}{l}\ln w^{f *} \\
D \text { (after) }\end{array}$ & $\begin{array}{l}-0.14 \\
(-0.93)\end{array}$ & $\begin{array}{c}-0.07 \\
(-1.49)\end{array}$ & $\begin{array}{c}-0.06 \\
(-1.28)\end{array}$ & $\begin{array}{c}0.05 \\
(0.58)\end{array}$ & $\begin{array}{c}0.05 \\
(0.46)\end{array}$ & $\begin{array}{c}-0.18 \\
(-0.99)\end{array}$ & $\begin{array}{c}0.17 \\
(1.22)\end{array}$ & $\begin{array}{c}-0.02 \\
(-0.31)\end{array}$ \\
\hline $\begin{array}{l}\ln w^{\text {k* }} \\
D \text { (after) }\end{array}$ & $\begin{array}{c}0.22 \\
(1.38)\end{array}$ & $\begin{array}{l}0.06 \\
(1.97)\end{array}$ & $\begin{array}{l}0.09 \\
(2.22)\end{array}$ & $\begin{array}{l}-0.08 \\
(-1.42)\end{array}$ & $\begin{array}{c}0.00 \\
(0.00)\end{array}$ & $\begin{array}{c}-0.07 \\
(-0.80)\end{array}$ & $\begin{array}{c}-0.07 \\
(-1.98)\end{array}$ & $\begin{array}{c}-0.07 \\
(-1.37)\end{array}$ \\
\hline Cap & $\begin{array}{c}1.07 \\
(11.66)\end{array}$ & $\begin{array}{c}0.62 \\
(10.45)\end{array}$ & $\begin{array}{c}0.51 \\
(6.16)\end{array}$ & $\begin{array}{c}0.61 \\
(2.98)\end{array}$ & $\begin{array}{c}0.39 \\
(2.80)\end{array}$ & $\begin{array}{c}0.44 \\
(7.22)\end{array}$ & $\begin{array}{c}0.72 \\
(6.89)\end{array}$ & $\begin{array}{c}0.66 \\
(7.24)\end{array}$ \\
\hline$b m$ & $\begin{array}{c}0.51 \\
(1.49)\end{array}$ & $\begin{array}{c}-0.17 \\
(-0.73)\end{array}$ & $\begin{array}{c}-0.34 \\
(-1.60)\end{array}$ & $\begin{array}{c}-0.67 \\
(-1.16)\end{array}$ & $\begin{array}{c}0.76 \\
(1.38)\end{array}$ & $\begin{array}{c}-0.05 \\
(-0.16)\end{array}$ & $\begin{array}{c}-0.16 \\
(-0.48)\end{array}$ & $\begin{array}{l}-0.26 \\
(0.91)\end{array}$ \\
\hline$H$ early & 0.81 & 0.28 & 0.33 & 0.36 & 0.53 & 0.44 & -0.03 & 0.27 \\
\hline $\begin{array}{l}\text { Market } \\
\text { Structure } \\
\text { early }\end{array}$ & $\mathrm{MC}$ & MC & $\mathrm{MC}$ & $\begin{array}{l}\text { Inc. (MC or } \\
\text { Monopoly) }\end{array}$ & $\begin{array}{l}\text { Inc. (MC or } \\
\text { Perfect } \\
\text { Comp.) }\end{array}$ & $\mathrm{MC}$ & $\begin{array}{c}\text { Inc. (MC } \\
\text { or } \\
\text { Monopoly) }\end{array}$ & $\overline{\mathrm{MC}}$ \\
\hline$H$ late & 0.97 & 0.29 & 0.36 & 0.41 & 0.54 & 0.22 & -0.03 & 0.10 \\
\hline $\begin{array}{l}\text { Market } \\
\text { Structure late }\end{array}$ & $\begin{array}{l}\text { Inc. (MC or } \\
\text { Perfect } \\
\text { Comp.) }\end{array}$ & MC & MC & $\begin{array}{l}\text { Inc. (MC or } \\
\text { Monopoly) }\end{array}$ & $\mathrm{MC}$ & $\begin{array}{l}\text { Inc. (MC or } \\
\text { Monopoly) }\end{array}$ & $\begin{array}{c}\text { Inc. (MC } \\
\text { or } \\
\text { Monopoly) }\end{array}$ & $\begin{array}{c}\text { Inc. (MC } \\
\text { or } \\
\text { Monopoly) }\end{array}$ \\
\hline $\begin{array}{l}\text { Test for } \\
\text { change in } H\end{array}$ & $\begin{array}{c}\text { Cannot reject } \\
\text { constancy } \\
(p=0.31)\end{array}$ & $\begin{array}{c}\text { Canno } \\
\text { t reject } \\
\text { consta } \\
\text { ncy } \\
(p=0.8 \\
2)\end{array}$ & $\begin{array}{c}\text { Cannot } \\
\text { reject } \\
\text { constancy } \\
(p=0.46)\end{array}$ & $\begin{array}{c}\text { Cannot } \\
\text { reject } \\
\text { constancy } \\
(p=0.13)\end{array}$ & $\begin{array}{c}\text { Cannot } \\
\text { reject } \\
\text { constancy } \\
(p=0.94)\end{array}$ & $\begin{array}{c}\text { Cannot } \\
\text { reject } \\
\text { decline } \\
(p=0.08)\end{array}$ & $\begin{array}{c}\text { Cannot } \\
\text { reject } \\
\text { constancy } \\
(p=0.98)\end{array}$ & $\begin{array}{c}\text { Cannot } \\
\text { reject } \\
\text { decline } \\
(p=0.01)\end{array}$ \\
\hline $\begin{array}{l}\text { No. of } \\
\text { Observations }\end{array}$ & 211 & 752 & 197 & 103 & 77 & 186 & 190 & 234 \\
\hline$R^{2}$ (adj.) & 0.98 & 0.91 & 0.99 & 0.97 & 0.97 & 0.96 & 0.97 & 0.97 \\
\hline $\begin{array}{l}\text { Year of } \\
\text { structural } \\
\text { break }\end{array}$ & 1997 & 1997 & 1997 & 1998 & 1997 & 1998 & 1998 & 1998 \\
\hline
\end{tabular}

Note: Regression includes fixed bank effects. $H$ statistic is the sum of the elasticities of interest rate revenues. The table reports the results from panel data regressions using yearly data on individual banks for the period 1994-1999. 'Test for change in $H^{\prime}$ ' refers to tests on whether the $\mathrm{H}$ statistic changed in the period starting with (and including) the year of the structural break, at the 5\% confidence level. "MC" (Monopolistic Competition) indicates that the hypotheses $\mathrm{H}>0$ and $\mathrm{H}<1$ could both not be rejected at the $2.5 \%$ confidence level (implying that the hypothesis of monopolistic competition cannot be rejected at the 5\% level). "Inc." (Inconclusive) indicates that the results are compatible with various types of market structure. The reported standard errors are robust (Hubert/White). 
Including Time Dummies

\begin{tabular}{|c|c|c|c|c|c|c|c|c|}
\hline & Argentina & Brazil & Chile & $\begin{array}{c}\text { Czech } \\
\text { Republic }\end{array}$ & Hungary & Mexico & Poland & Turkey \\
\hline $\ln w^{\prime}$ & $\begin{array}{c}0.24 \\
(2.00)\end{array}$ & $\begin{array}{c}0.24 \\
(3.13)\end{array}$ & $\begin{array}{c}0.31 \\
(5.13)\end{array}$ & $\begin{array}{c}0.34 \\
(4.10)\end{array}$ & $\begin{array}{c}0.41 \\
(4.17)\end{array}$ & $\begin{array}{c}0.11 \\
(0.04)\end{array}$ & $\begin{array}{c}0.27 \\
(4.58)\end{array}$ & $\begin{array}{c}0.29 \\
(3.72)\end{array}$ \\
\hline $\ln w^{f}$ & $\begin{array}{c}0.48 \\
(4.57)\end{array}$ & $\begin{array}{c}0.35 \\
(6.81)\end{array}$ & $\begin{array}{c}0.47 \\
(8.87)\end{array}$ & $\begin{array}{c}0.27 \\
(6.35)\end{array}$ & $\begin{array}{c}0.33 \\
(3.53)\end{array}$ & $\begin{array}{c}0.25 \\
(0.08)\end{array}$ & $\begin{array}{c}0.29 \\
(2.68)\end{array}$ & $\begin{array}{c}0.11 \\
(2.24)\end{array}$ \\
\hline $\ln w^{k}$ & $\begin{array}{c}0.13 \\
(1.37)\end{array}$ & $\begin{array}{c}0.07 \\
(2.89)\end{array}$ & $\begin{array}{l}-0.004 \\
(-0.14)\end{array}$ & $\begin{array}{c}-0.04 \\
(-2.25)\end{array}$ & $\begin{array}{l}.12 \\
(2.43)\end{array}$ & $\begin{array}{c}0.03 \\
(0.89)\end{array}$ & $\begin{array}{c}0.01 \\
(0.73)\end{array}$ & $\begin{array}{c}0.12 \\
(2.76)\end{array}$ \\
\hline $\begin{array}{l}\ln w^{1 *} \\
D \text { (after) }\end{array}$ & $\begin{array}{c}0.08 \\
(0.86)\end{array}$ & $\begin{array}{c}-0.01 \\
(-0.13)\end{array}$ & $\begin{array}{c}-0.01 \\
(-0.36)\end{array}$ & $\begin{array}{c}0.11 \\
(1.57)\end{array}$ & $\begin{array}{c}-0.36 \\
(-4.65)\end{array}$ & $\begin{array}{c}-0.05 \\
(-1.23)\end{array}$ & $\begin{array}{c}-0.13 \\
(-1.81)\end{array}$ & $\begin{array}{c}-0.05 \\
(-1.13)\end{array}$ \\
\hline $\begin{array}{l}\ln w^{/ *} \\
D \text { (after) }\end{array}$ & $\begin{array}{l}-0.28 \\
(2.35)\end{array}$ & $\begin{array}{c}-0.09 \\
(-1.84)\end{array}$ & $\begin{array}{c}-0.10 \\
(-2.30)\end{array}$ & $\begin{array}{c}0.34 \\
(3.73)\end{array}$ & $\begin{array}{c}0.01 \\
(0.08)\end{array}$ & $\begin{array}{c}0.23 \\
(1.85)\end{array}$ & $\begin{array}{c}-0.06 \\
(-0.45)\end{array}$ & $\begin{array}{c}0.02 \\
(0.45)\end{array}$ \\
\hline $\begin{array}{l}\ln w^{k *} \\
D \text { (after) }\end{array}$ & $\begin{array}{c}0.21 \\
(2.16)\end{array}$ & $\begin{array}{c}0.02 \\
(0.60)\end{array}$ & $\begin{array}{c}0.01 \\
(0.22)\end{array}$ & $\begin{array}{c}-0.10 \\
(-1.63)\end{array}$ & $\begin{array}{c}-0.22 \\
(-3.31)\end{array}$ & $\begin{array}{c}0.01 \\
(0.22)\end{array}$ & $\begin{array}{c}-0.03 \\
(-1.22)\end{array}$ & $\begin{array}{c}-0.09 \\
(-2.30)\end{array}$ \\
\hline$b m$ & $\begin{array}{c}1.29 \\
(3.79)\end{array}$ & $\begin{array}{c}0.55 \\
(3.56)\end{array}$ & $\begin{array}{c}0.25 \\
(2.27)\end{array}$ & $\begin{array}{c}-0.13 \\
(-0.45)\end{array}$ & $\begin{array}{c}0.61 \\
(2.02)\end{array}$ & $\begin{array}{c}0.82 \\
(3.92)\end{array}$ & $\begin{array}{c}0.16 \\
(0.73)\end{array}$ & $\begin{array}{c}-0.06 \\
(-0.29)\end{array}$ \\
\hline$H$ earfy & $\begin{array}{c}0.85 \\
(7.05)\end{array}$ & $\begin{array}{c}0.65 \\
(3.56)\end{array}$ & $\begin{array}{c}\mathbf{0 . 7 7} \\
(11.80)\end{array}$ & $\begin{array}{c}0.57 \\
(6.29)\end{array}$ & $\begin{array}{c}0.86 \\
(6.51)\end{array}$ & $\begin{array}{c}0.40 \\
(2.94)\end{array}$ & $\begin{array}{c}0.58 \\
(5.59)\end{array}$ & $\begin{array}{c}0.52 \\
(5.19)\end{array}$ \\
\hline $\begin{array}{l}\text { Market } \\
\text { Structure } \\
\text { early }\end{array}$ & $\begin{array}{l}\text { Inc. (MC or } \\
\text { Perfect } \\
\text { Comp.) }\end{array}$ & $\mathrm{MC}$ & $\overline{\mathrm{MC}}$ & $\mathrm{MC}$ & $\begin{array}{l}\text { Inc. (MC or } \\
\text { Perfect } \\
\text { Comp.) }\end{array}$ & $\mathrm{MC}$ & MC & $\mathrm{MC}$ \\
\hline$H$ late & $\begin{array}{c}0.87 \\
(5.94)\end{array}$ & $\begin{array}{c}0.57 \\
(9.57)\end{array}$ & $\begin{array}{c}0.67 \\
(8.44)\end{array}$ & $\begin{array}{c}0.94 \\
(7.85)\end{array}$ & $\begin{array}{c}0.29 \\
(1.81)\end{array}$ & $\begin{array}{c}0.59 \\
(5.97)\end{array}$ & $\begin{array}{c}0.36 \\
(5.42)\end{array}$ & $\begin{array}{c}0.39 \\
(3.47)\end{array}$ \\
\hline $\begin{array}{l}\text { Market } \\
\text { Structure late }\end{array}$ & $\begin{array}{l}\text { Inc. (MC or } \\
\text { Perfect } \\
\text { Comp.) }\end{array}$ & $\mathrm{MC}$ & $\overline{\mathrm{MC}}$ & $\begin{array}{l}\text { Inc. (MC or } \\
\text { Perf. Comp.) }\end{array}$ & $\mathrm{MC}$ & $\mathrm{MC}$ & $\begin{array}{c}\text { Inc. (MC } \\
\text { or } \\
\text { Monopol } \\
\text { y) }\end{array}$ & $\begin{array}{l}\text { Inc. (MC } \\
\text { or } \\
\text { Monopol } \\
\text { y) }\end{array}$ \\
\hline $\begin{array}{l}\text { Test for } \\
\text { change in } H\end{array}$ & $\begin{array}{c}\text { Cannot reject } \\
\text { constancy } \\
(p=0.08)\end{array}$ & $\begin{array}{c}\text { Cannot } \\
\text { reject } \\
\text { constancy } \\
(p=0.49)\end{array}$ & $\begin{array}{c}\text { Cannot } \\
\text { reject } \\
\text { decline } \\
(p=0.05)\end{array}$ & $\begin{array}{l}\text { Cannot reject } \\
\text { increase } \\
(p=0.02)\end{array}$ & $\begin{array}{l}\text { Cannot } \\
\text { reject } \\
\text { decline } \\
(p=0.00)\end{array}$ & $\begin{array}{c}\text { Cannot } \\
\text { reject } \\
\text { constancy } \\
(p=0.16)\end{array}$ & $\begin{array}{c}\text { Cannot } \\
\text { reject } \\
\text { constancy } \\
(p=0.06)\end{array}$ & $\begin{array}{c}\text { Cannot } \\
\text { reject } \\
\text { constanc } \\
y \\
(p=0.12)\end{array}$ \\
\hline $\begin{array}{l}\text { No. of } \\
\text { Observations }\end{array}$ & 211 & 752 & 197 & 103 & 77 & 186 & 190 & 254 \\
\hline$R^{2}$ (within) & 0.85 & 0.63 & 0.95 & 0.81 & 0.86 & 0.74 & 0.82 & 0.84 \\
\hline $\begin{array}{l}\text { Year of } \\
\text { structural } \\
\text { break }\end{array}$ & 1997 & 1997 & 1997 & 1998 & 1997 & 1998 & 1998 & 1998 \\
\hline
\end{tabular}

Note: Dependent variable: interest income/total assets. $H$ statistic is the sum of the elasticities of interest rate revenues. The table reports the results from panel data regressions using yearly data on individual banks for the period 1994-1999. "Test for change in $H$ " refers to tests on whether the $\mathrm{H}$ statistic changed in the period starting with (and including) the year of the structural break, at the 5\% confidence level. "MC" (Monopolistic Competition) indicates that the hypotheses H>0 and $\mathrm{H}<1$ could both not be rejected at the $2.5 \%$ confidence level. "Inc." (Inconclusive) indicates that the results are compatible with various types of market structure. The reported standard enrors are robust (Hubert/White). 


\section{Using Personnel Expenses Divided by Number of Employees as Proxy for $w^{l}$}

\begin{tabular}{|c|c|c|}
\hline & Argentina & Poland \\
\hline $\ln w^{T}$ & $\begin{array}{c}0.15 \\
(1.47)\end{array}$ & $\begin{array}{c}0.05 \\
(0.76)\end{array}$ \\
\hline $\ln w^{f}$ & $\begin{array}{c}0.41 \\
(3.97)\end{array}$ & $\begin{array}{c}0.77 \\
(13.74)\end{array}$ \\
\hline $\ln w^{k}$ & $\begin{array}{c}0.54 \\
(2.44)\end{array}$ & $\begin{array}{c}0.03 \\
(1.75)\end{array}$ \\
\hline $\begin{array}{l}\ln w^{l_{*}^{*}} \\
D \text { (after) }\end{array}$ & - & $\begin{array}{c}0.00 \\
(0.07)\end{array}$ \\
\hline $\begin{array}{l}\ln w f^{*} \\
D \text { (after) }\end{array}$ & - & $\begin{array}{c}-0.01 \\
(-0.36)\end{array}$ \\
\hline $\begin{array}{l}\ln w^{k_{*}^{*}} \\
D \text { (after) }\end{array}$ & - & $\begin{array}{c}0.03 \\
(1.75)\end{array}$ \\
\hline$b m$ & $\begin{array}{c}1.40 \\
(1.92)\end{array}$ & $\begin{array}{c}0.01 \\
(0.06)\end{array}$ \\
\hline$H$ early & - & 0.85 \\
\hline Market structure early & - & Inc. (MC or Perf. Comp.) \\
\hline$H$ late & 1.09 & 0.88 \\
\hline Market structure late & Inc. (MC or Perfect Competition) & Inc. (MC or Perf. Comp.) \\
\hline Test for change in $H$ & - & $\begin{array}{c}\text { Cannot reject constancy } \\
(p=0.83)\end{array}$ \\
\hline Number of observations & 143 & 97 \\
\hline$\overline{R^{2} \text { (adj.) }}$ & 0.79 & 0.87 \\
\hline Year of structural break & 1997 & 1998 \\
\hline
\end{tabular}

Note: Dependent variable: $\log$ of interest revenues divided by total assets. Regression includes fixed effects. $H$ statistic is the sum of the elasticities of interest rate revenues. The table reports the results from panel data regressions using yearly data on individual banks for the period 1994-1999. "Test for change in $H$ " refers to tests on whether the $H$ statistic changed in the period starting with (and including) the year of the structural break, at the 5\% confidence level. "MC" (Monopolistic Competition) indicates that the hypotheses $H>0$ and $H<1$ could both not be rejected at the $2.5 \%$ confidence level. "Inc." (Inconclusive) indicates that the results are compatible with various types of market structure. The reported standard errors are robust (Hubert/White). Only banks with more than 100 employees were included. 


\section{References}

Abut, Daniel, Sylvia Bigio, and John Mullen, 2001, "Revisiting Latin America's Bank Consolidation Process" Goldman Sachs Global Equity Research.

—_ 2000, "Banestado, Banespa, and Brazil's Banking Sector Consolidation" Goldman Sachs, Latin American Financial Services Monthly.

Abut, Daniel, Sylvia Bigio, and Daniel Siller, 2000, "Bank Consolidation in Latin America," Goldman Sachs Investment Research, Latin American Banks.

, 1999, "Focusing on the Costs Behind Argentina's 'Bancarization' Story," Goldman Sachs Investment Research, Financial Services.

Bank for International Settelments, 2001, "The Banking Industry in the Emerging Market Economies: Competition, Consolidation, and Systemic Stability," BIS Papers No. 4 (Basel).

Baumol, William J., John C. Panzar, and Robert D. Willig, 1982, Contestable Markets and the Theory of Industry Structure (New York: Harcourt Brace Jovanovich).

Berger, Allen N., Rebecca S. Demsetz, and Philip E. Strahan, 1999, "The Consolidation of the Financial Services Industry: Causes, Consequences, and Implications for the Future," Journal of Banking and Finance, Vol. 23, pp. 135-94.

Berger, Allen N., Leora Klapper, and Gregory F. Udell, 2001, "The Ability of Banks to Lend to Informationally Opaque Small Businesses" (unpublished; Washington D.C.: World Bank).

Bikker, Jacob A., and M. J. Groeneveld, 2000, "Competition and Concentration in the EU Banking Industry," Kredit und Kapital, Vol. 33, No.1, pp. 62-98.

Bonnaccorsi di Patti, Emilia, and Giovanni Dell' Ariccia, forthcoming, "Bank Competition and Firm Creation," Journal of Money, Credit and Banking.

Burdiso, Tamara, Marcelo Catena, and Laura D'Amato, 2001, "Bank Competition in Argentina: 1997-1999" (unpublished; Buenos Aires: Banco Central de la República Argentina).

Cetorelli, Nicola, 1999, "Competitive Analysis in Banking: Appraisal of the Methodologies," in Economic Perspectives (Chicago: Federal Reserve Bank of Chicago).

Claessens, Stijn, Asli Demirgüç-Kunt, and Harry Huizinga, 2001, Journal of Banking and Finance, 25, No. 5, pp. 891-911. 
- , Simeon Djankov, and Larry H.P. Lang, 1999, "Who Controls East Asian Corporations?" Policy Research Working Paper No. 2054 (Washington: World Bank).

Coccorese, Paolo, 1998, "Assessing the Competitive Conditions in the Italian Banking System: Some Empirical Evidence,” BNL Quarterly Review, No. 205, pp. 171-191.

Cordella, Tito, and Eduardo Levy Yeyati, 2002, "Financial Opening, Deposit Insurance, and Risk in a Model of Banking Competition," European Economic Review, 46, pp. $471-85$.

De Bandt, Olivier, and E. Philip Davis, 2000, "Competition, Contestability and Market Structure in European Banking Sectors on the eve of EMU," Journal of Banking and Finance 24, pp. 1045-66.

Feyzioğlu, Tarhan, and R. Gaston Gelos, 2000, "Why is Bank Lending so Low in Bulgaria?" in International Monetary Fund, "Bulgaria-Selected Issues and Statistical Appendix," Country Report No. 00/54.

Fitch IBCA, 1996, “The Turkish Banking System and Prudential Regulations.”

Goldberg, Linda, B., Gerard Dages, and Daniel Kinney, 2000, "Foreign and Domestic Bank Participation in Emerging Markets: Lessons from Mexico and Argentina," NBER Working Paper 7714 (Cambridge, Massachusetts: National Bureau of Economic Research).

Goldman Sachs, 2000, "Bank Consolidation in Latin America_Variations on a Theme."

Group of Ten, 2001, "Report on Consolidation in the Financial Sector" (Basel: Group of Ten).

Hannan, Timothy H., 1991, "The Functional Relationship Between Prices and Market Concentration: The Case of the Banking Industry," Finance and Economics Discussion Series No. 169 (Washington: Board of Governors of the Federal Reserve System), pp. 1-390.

Hempell, Hannah S., 2002, "Testing for Competition Among German Banks," Deutsche Bundesbank Discussion Paper 04/02.

International Monetary Fund, 2001, "International Capital Markets: Developments, Prospects, and Key Policy Issues," Washington, D.C.

__ 2000, "International Capital Markets: Developments, Prospects, and Key Policy Issues," Washington, D.C. 
Lang, G., 1997, "Wettbewerbsverhalten Deutscher Banken: Eine Panelanalyse auf Basis der Rosse-Panzar Statistik," Jahrbuch der Wirtschaftswissenschaften-Review of Economics, Vol. 48, No.1, pp. 21-38.

Mathieson, Donald, and Jorge Roldós, 2001, "Foreign Banks in Emerging Markets," in Open Doors: Foreign Participation in Financial Systems in Developing Countries, edited by Robert E. Litan, Paul Masson, and Michael Pomerleano, Brookings Institution Press, Washington D.C.

Matutes, C., and Xavier Vives, "Competition for Deposits, Fragility, and Insurance," Journal of Financial Intermediation, 5, pp. 184-216.

Molyneux, Philip, John Thornton, and D. Michael Lloyd-Williams, 1996, "Competition and Market Contestability in Japanese Commercial Banking," Journal of Economics and Business 48, pp. 33-45.

_ 1994, "Competitive Conditions in European Banking," Journal of Banking and Finance 18, pp. 445-459.

Moody's, 2000, “Argentina: Banking System Outlook," Investor Service.

Mooslechner, P., and Y. Schnitzer, 1995, "Structure-Performance in Banking: An Application of a Typical Universal Banking System," in K. Aiginger and J. Finsinger (eds.), Applied Industrial Organization, Dordrecht: Kluwer, pp. 167-86.

Nakane, Marcio, 2001, "A Test of Competition in Brazilian Banking," Banco Central do Brasil Working Paper No. 12.

Naranjo, Mauricio, 2000, "Apertura Financiera en Mexico," Paper presented at the Annual Meetings of the BCRA.

Nathan, A., and H. Neave, 1989, "Competition and Contestability in Canada's Financial System: Empirical Results," Canadian Journal of Economics, 22, pp. 576-94.

Panzar, John C., and James N. Ross, 1987, "Testing for 'Monopoly' Equilibrium," The Journal of Industrial Economics, Vol. 35, No. 4, pp. 443-456.

Peek, Joe, and Eric S. Rosengren, 2000, "Implications of the Globalization of the Banking Sector: The Latin American Experience," New England Economic Review, pp. 45-62.

Rajan, Raghuram G., and Luigi Zingales, 1998, "Which Capitalism? Lessons from the East Asian Crisis" (unpublished; Chicago: University of Chicago). 
Rime, Betrand, 1999, "Mesure du degré de concurrence dans le systeme bancaire suisse a l'aide du modele de Panzar et Rosse," Revue Suisse D'Economie Politique et de Statistique, Vol. 135, No.1, pp. 21-40.

Schargrodsky, Ernesto, and Federico Sturzenegger, 2000, "Banking Regulation and Competition with Product Differentiation," Journal of Development Economics 63, No. 1, pp. 85-111.

Shaffer S., 1989, "Competition in the US Banking Industry," Economic Letters, Vol. 29, No.4, pp. 349-353.

— 1982, "A Non-Structural Test for Competition in Financial Markets," in Bank Structure and Competition, Conference Proceedings, pp. 225-43 (Chicago: Federal Reserve Bank of Chicago).

Tirole, Jean, 1988, The Theory of Industrial Organization (Cambridge, Massachusetts: MIT Press).

Vansetti, Celina M., Philip Guarco, and Gregory W. Bauer, 2000, "The 'Fall' of Bancomer and the Future of the Indigenous Mega-Banks in Latin America," Moody's Investors Service.

Vesala, 1995, "Testing Competition in Banking: Behavioral Evidence from Finland," Bank of Finland Studies Working Paper No. E:1. 